\title{
ENDOPHYTIC BACTERIAL CONSORTIUM ORIGINATED FROM FORESTRY PLANT ROOTS AND THEIR NEMATICIDAL ACTIVITY AGAINST Meloidogyne incognita INFESTATION IN GREENHOUSE
}

\author{
Abdul Munif ${ }^{1}$, Supramanaㄹ, Elis Nina Herliyana², \\ Ankardiansyah Pandu Pradana ${ }^{3}$

\footnotetext{
${ }^{1}$ Department of Plant Protection, Faculty of Agriculture, IPB University, Jl Kamper, Kampus IPB Darmaga Wing 7 Level 5, Bogor, West Java, 16680, Indonesia

2 Department of Silviculture, Faculty of Forestry, IPB University, Jl Lingkar Akademik, Bogor, West Java, 16680, Indonesia

${ }^{3}$ Department of Plant Protection, Faculty of Agriculture, University of Jember, Jl Kalimantan No. 37, Jember, East Java, 68121, Indonesia
}

To link to this article: https://doi.org/10.11118/actaun201967051171

Received: 6. 4. 2019, Accepted: 7. 10. 2019

To cite this article: MUNIF ABDUL, SUPRAMANA, HERLIYANA ELIS NINA, PRADANA ANKARDIANSYAH PANDU. 2019. Endophytic Bacterial Consortium Originated from Forestry Plant Roots and Their Nematicidal Activity against Meloidogyne incognita Infestation in Greenhouse. Acta Universitatis Agriculturae et Silviculturae Mendelianae Brunensis, 67(5): 1171-1182.

\begin{abstract}
Yield loss due to root-knot nematode Meloidogyne incognita infection is reported to reach 35\%, depends on factors contributing to infection. Application of several endophytic bacterial isolates (bacterial consortium) to control pathogenic infection is reported to be more effective compared to the application of single bacterial isolate. This study was aimed to obtain endophytic bacterial consortium originated from forestry plant that is effective to control root-knot nematode. The study was conducted through bacterial isolation followed by biosafety test. Bacterial isolates that were found to be safe for plants and mammals and compatible with each other were further grouped as the endophytic bacterial consortium. Phenotypic characterization and physiological characteristics including Gram type, ability to produce protease, chitinase, and lipase enzymes as well as HCN volatile compound were also tested. Moreover, the ability to fix nitrogen and dissolve phosphate were also examined. The endophytic bacterial consortium consisted of several bacterial isolates was further tested for its ability to inhibit $M$. incognita egg hatching and increase J2 of $M$. incognita mortality in vitro. Furthermore, test on tomato plants infested with $500 \mathrm{~J} 2$ of $\mathrm{M}$. incognita was also performed in the greenhouse. Test results showed that 70 bacterial isolates were successfully isolated from Shorea sp., Swietenia sp., Albizia falcataria, Anthocephalus cadamba, and Juglans nigra. However, 34 bacterial isolates were observed to be safe (did not cause hypersensitivity reaction and did not produce hemolytic toxin). According to physiological characteristics, it was found that 25 isolates were able to produce protease enzyme, 26 isolates were able to produce chitinase enzyme, and 14 isolates were able to produce lipase enzyme. Moreover, it was also detected that 11 isolates were able to produce HCN volatile compound, 23 isolates were able to fix nitrogen (N), and 24 isolates were able to dissolve phosphate (P). Endophytic bacterial consortium obtained in this study was also observed to be able to inhibit $M$. incognita egg hatching up to $81.33 \%$ and increase J2 of $M$. incognita mortality up to $85 \%$ compared to control. In addition, the application of endophytic bacterial consortium was
\end{abstract}


also able to increase the growth of tomato plant infected with $M$. incognita, and suppress the severity of the root-knot disease. This study provided information that endophytic bacterial consortium originated from forestry plants has the potential as a biocontrol agent of $M$. incognita.

Keywords: bio-control, bio-stimulant enzyme, filtrate culture, root-knot nematode

\section{INTRODUCTION}

Root-knot nematode (Meloidogyne incognita) is reported to cause quite a big loss of many tropical plants. This nematode has a wide range of host, from horticultural crops to plants used for plantation. Rich et al. (2009) reported that $M$. incognita could infect, at the minimum, 3,000 plant species around the world. Yield loss due to $M$. incognita infection may reach $20 \%-60 \%$, depends on the number nematode population that attacks, type of plants infected, and environmental condition around plants (Bhatti and Jain, 1977). Root-knot nematode infection will lead to root-knot galls on plants infected. Later, gall will hinder transportation system as well as nutrient and water distribution from root to all parts of the plant. Disruption of a nutrient distribution process will result in unusual plant metabolism and inhibit plant growth. Moreover, disruption of water absorption to all parts of the plant causes the plant to lose a large amount of water. Thus, wilt will occur although water is sufficiently stored in the root area (Moens et al., 2009).

Root-knot nematode is also reported to be able to synergize with other pathogens and causes bigger yield loss. Bertrand et al. (2000) reported that simultaneous infection of $M$. incognita and Fusarium oxysporum in coffee plant could lead to higher yield loss. Besides synergizing with the pathogen from the fungi group, $M$. incognita is also reported to have the ability to synergize with the pathogen from the group of bacteria. Zakir and Bora (2009) mentioned that synergism between $M$. incognita and Ralstonia solanacearum led to bigger yield loss, and more difficult to control compared with single infection of $M$. incognita or single infection of $R$. solanacearum.

Many efforts have been conducted to control the population of $M$. incognita. However, further study is still required to develop a biocontrol product of $M$. incognita that is more effective, efficient, easy to apply, and environmentally friendly. One of the solutions to address this problem is the use of endophytic bacteria as a biocontrol agent of M. incognita (Wiratno et al., 2019). Endophytic bacteria are reported to have the ability to suppress severity caused by infection of the rootknot nematode. The previous study performed by Mardhiana et al. (2017) showed that endophytic bacteria originated from root of cyperus rotundus were reported to be effective in suppressing the population of root-knot nematode in cucumber up to $81.67 \%$. Moreover, application of endophytic bacteria by immersing tomato seed in endophytic bacterial suspension was also reported to effectively suppress the number of knot due to $M$. incognita infection (Pradana et al., 2016). In a separate study, application of $P$. chlororaphis strain Sm3 in strawberry was found to successfully suppress the population of root-lesion nematode (Pratylenchus penetrans) up to $61 \%$ besides enhancing the growth of the strawberry plant (Hackenberg et al., 2000).

As biocontrol agents, endophytic bacteria are reported to play dual roles. First, endophytic bacteria have the ability to suppress severity and yield loss due to nematode infection. There are two mechanisms performed by endophytic bacteria in suppressing severity and yield loss, those are the direct and indirect mechanism. Directly, endophytic bacteria are able to produce various nematicidal metabolites such as protease enzyme, chitinase enzyme, and HCN compound. Indirectly, endophytic bacteria have the ability to induce plants to produce defense compounds like PR-Protein (ReinholdHurek and Hurek, 2011; Rosenblueth and MartínezRomero, 2006). The ability of bacteria to stimulate plants to produce defense compound is known as Induced Systemic Resistance (ISR) phenomenon (Shoresh et al., 2010).

Endophytic bacteria are investigated to have the ability to adapt to various plants. Hallmann et al. (2009) reported that endophytic bacterial isolated from coffee plants were able to control Meloidogyne spp. in a tomato plant. In another study, Harni and Munif (2012) found that endophytic bacteria isolated from forestry plants were able to control yellow disease in pepper plants. This result shows that exploration of endophytic bacteria from various plants such as forestry plants should be continuously done to obtain bacterial candidates that have great ability to control the infection of root-knot nematode in the field.

The endophytic bacterial consortium is defined as all bacteria living within plant tissues and can be cultured on artificial media. Application of endophytic bacterial consortium is a new breakthrough in the development of biocontrol agents of plant parasitic nematodes. Bacteria have a specific mode of actions and are different from each other. Bacteria that are unable to produce antimicrobial compounds may have a function in the process of biological control (Ryan et al., 2008). Therefore, the use of more species of bacteria in controlling the RKN may have a great opportunity to succeed. This study was aimed to formulate the most effective endophytic bacterial consortium originated from potential forestry plant roots as a biocontrol agent of $M$. incognita in tomato. 


\section{MATERIALS AND METHODS}

\section{Study Area}

This research was done as a laboratory and greenhouse experiment in the Laboratory of Plant Nematology (Department of Plant Protection) and the greenhouse of the Faculty of Agriculture, IPB University, Bogor, Indonesia.

\section{Isolation and Purification of Endophytic Bacterial Isolates}

Endophytic bacteria were isolated from the roots of 2-years-old plants of Shorea sp., Swietenia sp., Albizia falcataria, Anthocephalus cadamba, and Juglans nigra. Each plant is only taken one individual to be used as a source of endophytic bacteria. Samples were taken around IPB University, Indonesia. Isolation was done through surface sterilization method as performed by Hallmann et al. (2006). About $1 \mathrm{~g}$ of roots from each plant was washed with water to remove soil particles attached to roots. Clean roots were further sterilized through immersion in 70\% alcohol and 1\% NaOCl solvent, consecutively. Immersion in each sterilant was conducted for 1 minute. Later, roots were washed 3 times with sterile distilled water. Sterile root samples were macerated using a sterile mortar and added with sterile distilled water at a ratio of 1:10 (w/v). About $0.1 \mathrm{ml}$ of suspension produced from the maceration process was inoculated on 20\% Tryptic Soy Agar (TSA) media and incubated for 72 hours. Bacterial colonies that grew and had different colony characteristics were further purified on 100\% TSA media.

\section{Hypersensitivity Reaction Test in Tobacco Leaves}

Endophytic bacterial isolates were grown on TSA $100 \%$ for 24 hours. Bacterial cells grown on the media were further harvested using $2 \mathrm{ml}$ of sterile distilled water. The suspension formed was infiltrated to the bottom lamina part of tobacco leaves (Kemloko 3 variety) and incubated for 48 hours. Bacterial isolates found to cause necrosis on tobacco leaves were eliminated and would not be used for the further test, while isolates that did not cause necrosis on leaves were used for the further test (Klement and Goodman, 1967).

\section{Hemolytic Activity Test on Blood Agar}

Bacterial isolates that did not cause necrosis in hypersensitivity test were used in this test. Bacterial isolates were grown on blood agar media and incubated for 24 hours. Bacterial isolates that formed dark zone (produced a-hemolytic toxin), formed clear zone (produced $\beta$-hemolytic toxin) and formed clear zone as well as a quite dark area around the clear zone (produced $\alpha \beta$ - hemolytic toxin) were eliminated and did not used for the further test (Irma et al., 2018).

\section{Characterization of Endophytic Bacteria}

\section{Phenotypic Characters of Endophytic Bacteria Colonies}

Phenotypic characters of bacteria observed in this study included the shape of colony, size, texture, color, and elevation.

\section{Gram Staining}

Endophytic bacteria Gram staining was conducted using the Himedia Gram-stain kit. Bacterial cell staining was done following the method explained by (Claus, 1992). Bacteria cells with violet color after staining and rinsing with Gram-stain kit were Gram-positive bacteria, while Gram-negative bacteria were observed to have red bacterial cells after staining and rinsing with Gram-stain kit.

\section{Proteolytic Activity}

Proteolytic activity was tested using skim milk agar media. Later, TSA media consisted of $15 \mathrm{~g}$ of Tryptic Soy Broth (TSB), 7.5 g of bacto agar, and $400 \mathrm{ml}$ of distilled water was sterilized in the autoclave. The sterile TSA media was further dissolved. At the temperature of $\pm 50-60{ }^{\circ} \mathrm{C}$, TSA media was added with $100 \mathrm{ml}$ of pasteurized skim milk solution. Proteolytic activity was indicated by a clear zone around the colonies of bacteria, 48 hours after treatment (Sokol et al., 1979).

\section{Chitinolytic Activity}

The test was performed using 1\% chitin media that consisted of bacto agar (15 g), glucose (5 g), bacterial peptone (2 g), colloidal chitin (10 g), $\mathrm{K}_{2} \mathrm{HPO}_{4}(0.5 \mathrm{~g}), \mathrm{MgSO}_{4}(0.5 \mathrm{~g})$, and $\mathrm{NaCl}$ (0.5 g). All materials were dissolved in sterile distilled water to reach $1,000 \mathrm{ml}$ volume of suspension, and the $\mathrm{pH}$ of media was set at 6.2. Later, media was sterilized in the autoclave and sterile media was poured into the petri dish. Bacterial isolates were streaked on the media and incubated for 3-5 days. Chitinolytic activity was observed with the appearance of a clear zone around bacterial streak (Nurdebyandaru et al., 2010).

\section{Lipolytic Activity}

One liter of media consisted of $8 \mathrm{~g}$ of nutrient broth, $4 \mathrm{~g}$ of sodium chloride, $10 \mathrm{~g}$ of agar, and $0.001 \%$ rhodamine B solution at pH of 7 . Olive oil $(2.5 \%)$ was added shortly before the media was poured into the petri dish. Lipolytic activity was observed using UV light, 48 hours after bacteria were streaked on the test media (El-Deeb et al., 2013).

\section{HCN Production}

The media used in this test was $1,000 \mathrm{ml}$ TSA media that was previously added with $4.4 \mathrm{~g}$ of glycine. Media was further poured into a petri dish and bacterial isolates were streaked on the media. 
Filter paper that has been immersed in cyanide detection solution (CDS) was attached to the inside lid of the petri dish. The CDS solution has consisted of $2 \mathrm{~g}$ of picric acid and $8 \mathrm{~g}$ of sodium carbonate dissolved in sterile distilled water to reach a volume of $200 \mathrm{ml}$.

Bacterial isolates were streaked on TSA media that had been added with glycine. Filter paper previously immersed in CDS solution was attached to the upper part of the petri dish. Bacteria in the petri dish were further incubated for 5-7 days at ambient temperature. Bacteria are considered to have the ability to produce HCN if there is a color change on filter paper, from yellow to orange or brown, during the $5^{\text {th }}-7^{\text {th }}$ day. The more solid the color change, the higher the ability of bacteria to produce HCN (Kumar et al., 2012).

\section{Nitrogen Fixing Activity}

The test was conducted on the NFB semi-solid medium at a pH of 6.8. This media consisted of malic acid (5 g), $\mathrm{K}_{2} \mathrm{HPO}_{4}(0.5 \mathrm{~g}), \mathrm{MgSO}_{4} .7 \mathrm{H}_{2} \mathrm{O}(0.2 \mathrm{~g}$ ), $\mathrm{NaCl}$ (0.1 g), $\mathrm{CaCl}_{2} .2 \mathrm{H}_{2} \mathrm{O}$ (0.02 g), micronutrient (2 ml), Bromthymol blue (2 ml), Fe (III) EDTA (1.64\%) (4 ml), vitamins solution (1 ml), and bactoagar (0.5 g). Micronutrient used in this test had a composition of $\mathrm{CuSO}_{4} .5 \mathrm{H}_{2} \mathrm{O}(0.4 \mathrm{~g}), \mathrm{ZnSO}_{4} \cdot 7 \mathrm{H}_{2} \mathrm{O}$ (0.12 g), $\mathrm{H}_{3} \mathrm{BO}_{3}$ (1.4 g), $\mathrm{Na}_{2} \mathrm{MoO}_{4} \cdot 2 \mathrm{H}_{2} \mathrm{O}$ (1 g), $\mathrm{MnSO}_{4} \cdot \mathrm{H}_{2} \mathrm{O}$ (1.5 g) dissolved in $1,000 \mathrm{ml}$ of distilled water. Vitamin solution had a composition of biotin (10 mg), Pyridoxine HCL (20 mg), and dissolved in $1,000 \mathrm{ml}$ of distilled water.

About $1 \mathrm{ml}$ of bacterial isolates grown in TSB media for 24 hours were put into $9 \mathrm{ml}$ of NFB semi-solid medium in a closed test tube. The ability of bacteria to fix nitrogen is indicated with the existence of pellicle around the surface of media (Baldani et al., 1986).

\section{Phosphate Dissolving Activity}

The test was performed by streaking bacterial isolates on Pikovskayas Agar medium (Himedia, India). About $31.3 \mathrm{~g}$ of Pikovskayas Agar powder were dissolved in $1,000 \mathrm{ml}$ of distilled water and sterilized in the autoclave. Bacterial culture on Pikovskaya's Agar was further incubated for 48-72 hours. The ability of bacteria in dissolving phosphate is indicated by the presence of a clear zone around bacterial streak (Mehta and Nautiyal, 2001).

\section{Bacterial Isolates Maintenance}

Pure cultures of each bacterial cells were maintained in Tryptic Soy Broth, amended with $20 \%$ glycerol (Fisher Scientific) and stored at $-80{ }^{\circ} \mathrm{C}$. The stored bacterial isolate will be used in further testing or studies, as well as for confirmation of results.

\section{Compatibility Test of Endophytic Bacteria}

Compatibility test was conducted using a dualculture method. Endophytic bacteria were grown in tryptic soy broth (TSB) media for 24 hours. A total of $100 \mathrm{ml}$ of bacteria was spread on TSA media in $9 \mathrm{~cm}$ diameter petri dishes. As the bacteria spread, a filter paper was placed on the media and then dripped with $25 \mathrm{ml}$ of the suspension of other bacteria from the same plant roots. Antagonistic properties of bacteria would form a clear zone that would not be used as test material.

\section{Preparation of Endophytic Bacterial Consortium}

Non-antagonistic bacteria were grown in TSB media for 24 hours. Furthermore, $100 \mathrm{ml}$ of the suspension of each bacteria from the same plant roots was simultaneously cultured in TSB media. The culture was then used for the further test, termed as an endophytic bacterial consortium.

\section{Propagation of Meloidogyne incognita Inoculum}

M. incognita used in this test was the collection of the Laboratory of Plant Nematology - IPB University. The nematodes were cultured on Tantyna F-1 variety of tomato plants grown in sterile soil to ensure the purity of $M$. incognita culture.

\section{Effect of Filtrate Culture of Endophytic Bacterial Consortium on Nematode Egg Hatching}

The endophytic bacterial consortium was grown in $100 \mathrm{ml}$ of TSB media and incubated for 24 hours on a shaker at $150 \mathrm{rpm}$. Bacterial cells were further separated from the suspension by performing centrifugation at 12,000 rpm for 15 minutes. The supernatant formed was filtered using a sterile syringe filter at size of $0.22 \mu \mathrm{m}$ and a diameter of $25 \mathrm{~mm}$. The supernatant obtained was used in this test.

A total of $50 \mathrm{M}$. incognita eggs previously sterilized with 600 ppm of Streptomycin sulfate were put into petri dish at a diameter of $5 \mathrm{~cm}$ consisted of $5 \mathrm{ml}$ of filtrate culture of endophytic bacterial consortium and incubated for 48 hours. As a control, $M$. incognita eggs were added into sterile distilled water. The observation was conducted 14 days after treatment. This test applied a completely randomized design with 3 replicates. The observation was conducted on the percentage of eggs that hatched and data obtained were further analyzed using DSAASTAT program version 1.021 (Padgham and Sikora, 2007).

\section{Effect of Filtrate Culture of Endophytic Bacterial Consortium on Mortality of J2 of $M$. incognita}

A total of 100 J2 of $M$. incognita of the same age were put into $5 \mathrm{ml}$ of filtrate culture of endophytic bacterial consortium. The test was done using 
a petri dish at a diameter of $5 \mathrm{~cm}$ for 24 hours. This test followed a completely randomized design with 3 replicates. TSB was used as the control to ensure that nematodes were dead due to the effect of filtrate culture. The observation was conducted 24 hours after treatment by calculating the percentage of dead nematodes. Moreover, J2 of $M$. incognita was considered dead if it did not show any movements after 2 hours in contact with sterile water. Data analysis was done using DSAASTAT program version 1.021 (Ashoub and Amara, 2010).

\section{Selection of Endophytic Bacterial Consortium as Control Agent of RKN and Plant Growth Promoter}

The endophytic bacterial consortium was grown in TSB media for 24 hours. The bacterial suspension was further used to immerse Tantyna F1 variety of tomato seeds that were previously sterilized with 1\% NaOCl. Seed immersion was conducted for 12 hours at room temperature. Later, treated seeds were sown in sterile soil. After 4 main leaves appeared, tomato seeds were moved to pot at a diameter of $15 \mathrm{~cm}$. The test was conducted by following a randomized block design with 3 replicates consisted of 2 treatment unit of each. After being planted in the pot, tomato plants were watered with $100 \mathrm{ml}$ of bacterial consortium suspension at a density of $10^{8} \mathrm{CFU} \mathrm{ml}{ }^{-1}$ at the first, second, and fifth week. Watering was performed in the afternoon at 16.00-17.00.

Infestation of root-knot nematode was done 1 month after tomato seeds were moved to pot. About 500 of $J 2$ of $M$. incognita of the same age were infested to tomato plant root area. Observation and measurement were done 40 days after nematode infestation. Characters measured in this test included the characters of agronomy and pathology. Agronomic characters consisted of plant height, root length, both fresh and dry weight of plant. Moreover, pathological characters observed were the number of J2 of $M$. incognita per $5 \mathrm{~g}$ of roots, the number J2 of $M$. incognita per $100 \mathrm{ml}$ of soil, and the number of gall at the root. Invasive larvae of $M$. incognita on roots were extracted by cutting $5 \mathrm{~g}$ of roots with a size of $1 \mathrm{~cm}$, and then the root pieces were placed in the mist chamber for three days following. Furthermore, J2 of $M$. incognita in the soil were extracted using the centrifugal-floatation method (EPPO, 2013). The number of extracted J2 of $M$. incognita is then calculated manually under a microscope. The data obtained were analyzed through analysis of variance. Analysis of Duncan Multiple Range Test (DMRT) at a confidence level of 95\% might be applied if the result was significantly different. The analysis was performed using DSAASTAT program version 1.021 (Abo-Elyousr et al., 2010).

\section{RESULTS AND DISCUSSION}

\section{Biosafety of Endophytic Bacteria}

Seventy isolates of endophytic bacteria were isolated from the roots of Shorea sp., Swietenia sp., A. falcataria, A. cadamba, and J. nigra. There were 17 isolates from plant roots of Shorea sp., 11 isolates from the plant roots of Swietenia sp., 15 isolates from plant roots of $A$. falcataria, 18 isolates from plant roots of $A$. cadamba, and 9 isolates from plant roots of $J$. nigra. Based on the result of the biosafety test, no isolates were safe to be used as biological agent. Among 70 isolates isolated, 30\% caused necrosis during the test of hypersensitivity reaction. Since isolates that caused necrosis in hypersensitivity test were not used in the further test, there were only 49 isolates tested for their safety in the hemolysis test. Hemolysis test showed that $15.71 \%$ of endophytic bacteria were able to produce $\beta$-hemolytic toxin and other 5.71\% were able to produce a-hemolytic toxin. Bacteria which did not cause necrosis in hypersensitivity test and did not produce hemolytic toxin were used in the further test. Biosafety test showed that nine isolates from plant roots of Shorea sp., six isolates from plant roots of Swietenia sp. seven isolates from plant roots of $A$. falcataria, eight isolates from plant roots of $A$. cadamba, and four isolates from plant roots of J. nigra could be used in the test (Tab. I).

\section{Phenotypic Characters and Gram Type of Endophytic Bacteria}

Among 34 isolates of endophytic bacteria, 64.71\% of colonies were circular, $11.76 \%$ were rhizoid, $17.65 \%$ were irregular, and 5.88\% were filamentous of shape. Colony size of endophytic bacteria also varied, observation showed that $11.76 \%$ of punctiform, $32.35 \%$ of small, $26.47 \%$ of medium and $29.41 \%$ of large size. Moreover, $73.53 \%$ were rough texture and $26.47 \%$ were smooth texture. There were five colors of endophytic bacterial colonies, namely white (55.88\%), yellow (14.71\%), brown (11.76\%), red (11.76\%), and green (5.88\%). Furthermore, elevation of endophytic bacteria colonies consisted of 5 types, those were flat (35.29\%), raised (29.41\%), convex (20.59\%), umbonate (5.88\%), and pulvinate (8.82\%). Based on the observation, $67.65 \%$ of endophytic bacteria were Gram-positive, and 32.35\% were Gramnegative (Supplementary Material 1).

\section{Physiological Characteristics of Endophytic Bacteria}

Based on the test result of all isolates, it was found that 25 isolates were able to produce protease enzyme, 26 isolates were able to produce chitinase enzyme, and 14 isolates were able to produce lipase enzyme. Furthermore, 11 isolates were also detected to have the ability to produce a volatile compound of HCN. Several bacteria tested were 
I: The result of biosafety test of endophytic bacterial isolate originated from plant roots of Shorea sp., Swietenia sp., A. falcataria, A. cadamba, and J. nigra

\begin{tabular}{|c|c|c|c|c|c|c|c|}
\hline Plant & Isolat code & $\begin{array}{c}\text { Hypersensitive } \\
\text { reaction }\end{array}$ & $\begin{array}{c}\text { Hemolysis } \\
\text { activity }\end{array}$ & Plant & Isolat code & $\begin{array}{c}\text { Hypersensitive } \\
\text { reaction }\end{array}$ & $\begin{array}{c}\text { Hemolysis } \\
\text { activity }\end{array}$ \\
\hline Shorea sp. & Mrt-1 & - & - & A. falcataria & Alb-8 & - & - \\
\hline Shorea sp. & Mrt-2 & - & - & A. falcataria & Alb-9 & + & $\mathrm{x}$ \\
\hline Shorea sp. & Mrt-3 & - & - & A. falcataria & Alb-10 & + & $\mathrm{x}$ \\
\hline Shorea sp. & Mrt-4 & - & $\beta$ & A. falcataria & Alb-11 & - & - \\
\hline Shorea sp. & Mrt-5 & - & - & A. falcataria & Alb-12 & + & $\mathrm{x}$ \\
\hline Shorea sp. & Mrt-6 & + & $\mathrm{x}$ & A. falcataria & Alb-13 & - & - \\
\hline Shorea sp. & Mrt-7 & - & - & A. falcataria & Alb-14 & - & - \\
\hline Shorea sp. & Mrt-8 & + & $\mathrm{x}$ & A. falcataria & Alb-15 & - & - \\
\hline Shorea sp. & Mrt-9 & + & $\mathrm{x}$ & A. cadamba & Jab-1 & - & $\beta$ \\
\hline Shorea sp. & Mrt-10 & + & $\mathrm{x}$ & A. cadamba & Jab-2 & - & - \\
\hline Shorea sp. & Mrt-11 & - & a & A. cadamba & Jab-3 & + & $\mathrm{x}$ \\
\hline Shorea sp. & Mrt-12 & - & - & A. cadamba & Jab-4 & + & $\mathrm{x}$ \\
\hline Shorea sp. & Mrt-13 & - & - & A. cadamba & Jab-5 & + & $\mathrm{x}$ \\
\hline Shorea sp. & Mrt-14 & - & - & A. cadamba & Jab-6 & - & - \\
\hline Shorea sp. & Mrt-15 & - & - & A. cadamba & Jab-7 & - & - \\
\hline Shorea sp. & Mrt-16 & - & $\beta$ & A. cadamba & Jab-8 & + & $\mathrm{x}$ \\
\hline Shorea sp. & Mrt-17 & - & $\beta$ & A. cadamba & Jab-9 & - & - \\
\hline Swietenia sp. & Mhg-1 & - & - & A. cadamba & Jab-10 & - & $\beta$ \\
\hline Swietenia sp. & Mhg-2 & - & $\beta$ & A. cadamba & Jab-11 & - & - \\
\hline Swietenia sp. & Mhg-3 & + & $\mathrm{x}$ & A. cadamba & Jab-12 & - & - \\
\hline Swietenia sp. & Mhg-4 & - & $\beta$ & A. cadamba & Jab-13 & - & - \\
\hline Swietenia sp. & Mhg-5 & + & $\mathrm{x}$ & A. cadamba & Jab-14 & + & $\mathrm{x}$ \\
\hline Swietenia sp. & Mhg-6 & + & $\mathrm{x}$ & A. cadamba & Jab-15 & - & - \\
\hline Swietenia sp. & Mhg-7 & - & - & A. cadamba & Jab-16 & - & $\beta$ \\
\hline Swietenia sp. & Mhg-8 & - & - & A. cadamba & Jab-17 & - & $\beta$ \\
\hline Swietenia sp. & Mhg-9 & - & - & A. cadamba & Jab-18 & - & a \\
\hline Swietenia sp. & Mhg-10 & - & - & J. nigra & Wlt-1 & - & - \\
\hline Swietenia sp. & Mhg-11 & - & - & J. nigra & Wlt-2 & - & - \\
\hline A. falcataria & Alb-1 & - & - & J. nigra & Wlt-3 & - & - \\
\hline A. falcataria & Alb-2 & - & $\beta$ & J. nigra & Wlt-4 & + & $\mathrm{x}$ \\
\hline A. falcataria & Alb-3 & + & $\mathrm{x}$ & J. nigra & Wlt-5 & + & $\mathrm{x}$ \\
\hline A. falcataria & Alb-4 & + & $\mathrm{x}$ & J. nigra & Wlt-6 & + & $\mathrm{x}$ \\
\hline A. falcataria & Alb-5 & - & a & J. nigra & Wlt-7 & - & - \\
\hline A. falcataria & Alb-6 & - & a & J. nigra & Wlt-8 & + & $\mathrm{x}$ \\
\hline A. falcataria & Alb-7 & - & - & J. nigra & Wlt-9 & - & $\beta$ \\
\hline
\end{tabular}

Note: (-) did not cause hypersensitivity reaction or hemolysis; (+) caused hypersensitivity reaction indicated by the existence of necrosis on tobacco leaves; $(\alpha)$ bacteria were able to produce $a$-hemolytic toxin, $(\beta)$ bacteria were able to produce $\beta$-hemolytic toxin, (x) bacteria were not tested in hemolysis test for not passing hypersensitivity reaction test 
also potential to enhance plant growth as shown by the test result that 23 isolates successfully fixed nitrogen $(\mathrm{N})$ and 24 isolates were able to dissolve phosphate (P) (Tab. II).

\section{Compatibility of Endophytic Bacterial Isolates}

All bacteria tested were known to be compatible with other bacteria from the same plant roots. There were no antagonistic isolates as evidenced by the appearance of a clear zone during the compatibility test. This showed that all isolates could be used in the further test.

II: Physiological activity of endophytic bacterial isolates originated from plant roots of Shorea sp., Swietenia sp., A. falcataria, A. cadamba, and J. nigra

\begin{tabular}{|c|c|c|c|c|c|c|}
\hline Isolate code & $\begin{array}{c}\text { Proteolytic } \\
\text { activity }\end{array}$ & $\begin{array}{l}\text { Chitinolytic } \\
\text { activity }\end{array}$ & $\begin{array}{c}\text { Lipolytic } \\
\text { activity }\end{array}$ & $\begin{array}{l}\text { Production } \\
\text { of HCN }\end{array}$ & $\begin{array}{l}\text { Nitrogen } \\
\text { fixing }\end{array}$ & $\begin{array}{l}\text { Phosphate } \\
\text { dissolving }\end{array}$ \\
\hline Mrt-1 & + & + & - & - & + & + \\
\hline Mrt-2 & + & + & + & - & + & - \\
\hline Mrt-3 & + & - & + & - & - & + \\
\hline Mrt-5 & + & + & - & - & + & + \\
\hline Mrt-7 & - & + & - & - & - & + \\
\hline Mrt-12 & + & + & - & - & + & - \\
\hline Mrt-13 & + & - & - & + & - & + \\
\hline Mrt-14 & - & + & - & - & + & + \\
\hline Mrt-15 & + & + & + & - & - & + \\
\hline Mhg-1 & + & - & - & + & + & - \\
\hline Mhg-7 & + & + & - & - & - & - \\
\hline Mhg-8 & + & - & + & - & + & + \\
\hline Mhg-9 & - & + & - & - & + & + \\
\hline Mhg-10 & + & + & + & + & - & + \\
\hline Mhg-11 & - & + & - & - & + & - \\
\hline Alb-1 & - & + & - & - & + & + \\
\hline Alb-7 & + & + & - & + & + & - \\
\hline Alb-8 & + & - & + & - & + & + \\
\hline Alb-11 & + & + & - & - & + & - \\
\hline Alb-13 & - & + & - & + & + & - \\
\hline Alb-14 & + & + & + & + & + & + \\
\hline Alb-15 & - & + & - & - & - & + \\
\hline Jab-2 & + & - & - & + & + & + \\
\hline Jab-6 & + & - & + & - & + & + \\
\hline Jab-7 & + & + & - & - & - & + \\
\hline Jab-9 & - & + & + & - & - & - \\
\hline Jab-11 & + & + & + & + & + & + \\
\hline Jab-12 & - & + & - & - & + & - \\
\hline Jab-13 & + & + & + & - & + & + \\
\hline Jab-15 & + & + & - & + & + & + \\
\hline Wlt-1 & + & + & + & - & - & + \\
\hline Wlt-2 & + & - & + & + & + & + \\
\hline Wlt-3 & + & + & + & - & - & + \\
\hline Wlt-7 & + & + & - & + & + & + \\
\hline
\end{tabular}

Note: (+) bacteria were able to produce compound tested; (-) bacteria were not able to produce compound tested 
III: The ability of endophytic bacterial consortium to inhibit egg hatching and increase mortality of 2 of $M$. incognita in vitro

\begin{tabular}{lcc}
\hline Consortium Code & Inhibition of eggs hatching of $M$. incognita (\%) & Mortality of J2 of $M$. incognita (\%) \\
\hline CSR MRT & $60.67^{\mathrm{b}} \pm 1.15$ & $85.00^{\mathrm{c}} \pm 1.73$ \\
CSR MHG & $70.00^{\mathrm{c}} \pm 4.00$ & $77.00^{\mathrm{b}} \pm 2.00$ \\
CSR ALB & $57.33^{\mathrm{b}} \pm 3.06$ & $79.00^{\mathrm{b}} \pm 2.65$ \\
CSR JAB & $67.33^{\mathrm{c}} \pm 3.06$ & $76.67^{\mathrm{b}} \pm 2.52$ \\
CSR WLT & $81.33^{\mathrm{d}} \pm 3.06$ & $75.00^{\mathrm{b}} \pm 3.00$ \\
Control & $0.00^{\mathrm{a}}$ & $0.00^{\mathrm{a}}$ \\
\hline
\end{tabular}

Note: Values followed by different superscript letters are significant at $P \leq 0.05$ over control

\section{The Ability of Endophytic Bacteria Consortium to Inhibit Egg Hatching and Increase Mortality of $M$. incognita in Vitro}

Endophytic bacteria originated from the roots of the same plant were cultured in a suspension. The suspension was hereinafter termed endophytic bacterial consortium. There were 5 endophytic bacterial consortiums, those were shorea sp. (CSR MRT), Swietenia sp. (CSR MHG), A. falcataria (CSR ALB), A. cadamba (CSR JAB), and J. nigra (CSR WLT). The test showed that all filtrate cultures of the consortium tested effectively inhibited eggs hatching of $M$. incognita and were able to kill J2 of M. incognita.

In general, all endophytic bacterial consortiums were able to inhibit egg hatching of $M$. incognita and increase the mortality of J2 of $M$. incognita in vitro. The best endophytic bacterial consortium in inhibiting egg hatching of $M$. incognita was CSR WLT with an average percentage of 81.33\%, followed with other consortiums, those were CSR MHG (70\%), CSR JAB (67.33\%), CSR MRT (60.67\%), and CSR ALB (57.33\%). Moreover, all endophytic bacterial consortiums were also reported to have the ability to increase the mortality of J2 of $M$. incognita in vitro. The best endophytic bacterial consortium to increase mortality of $\mathrm{J} 2$ of $M$. incognita was CSR MRT with an average mortality of $85 \%$ and followed by CSR ALB (79\%), CSR MHG (77\%), CSR JAB (76.67\%), and CSR WLT (75\%) (Tab. III).

\section{The Ability of Endophytic Bacterial Consortium as Biocontrol Agents of $M$. incognita in Greenhouse}

Application of endophytic bacterial consortium was able to suppress the negative effect of $M$. incognita infection. Plants with a treatment of endophytic bacterial consortium showed better growth performance compared to the plant that did not obtain treatment of endophytic bacterial consortium. Plants given treatment were found to be higher than the control plant. There were height increase of 20.09\% (CSR MRT), 20.24\% (CSR MHG), 14.52\% (CSR ALB), 24.47\% (CSR JAB), and 26.14\% (CSR WLT). Furthermore, there was length increase in plant roots given treatment of endophytic bacterial consortium of 23.44\% (CSR MRT), 8.40\% (CSR MHG), 31.45\% (CSR ALB), 34.12\% (CSR JAB) and $17.80 \%$ (CSR WLT) compared to the root length of control plant. Fresh weight of plants with the treatment of endophytic bacterial consortium (CSR MRT, CSR ALB, and CSR WLT) was also found to be higher of $8.30 \%, 12.15 \%$, and $15.69 \%$, respectively compared with the fresh weight of control plant. Moreover, endophytic bacterial consortiums that obtained better result compared to control in term of plant dry weight were CSR JAB (28.82\%) and CSR WLT $(29.09 \%)$

Application of bacterial consortium was able to suppress $\mathrm{J} 2$ of $M$. incognita population in roots up to 54.88\% (CSR MRT), 41.46\% (CSR MHG), 40.85\% (CSR ALB), 40.24\% (CSR JAB) and 55.49\% (CSR WLT). Population of J2 of $M$. incognita in soil given treatment of endophytic bacterial consortium also decreased to $30.97 \%$ (CSR MRT), 34.52\% (CSR MHG), 30.97\% (CSR ALB), 24.19 (CSR JAB), and 30\% (CSR WLT). Declining J2 of $M$. incognita population in root tissue and soil further decreased the number of root-knot gall up to $21.43 \%$ (CSR MRT), $21.80 \%$ (CSR MHG), 23.43\% (CSR ALB), 20.05\% (CSR JAB), and 21.18\% (CSR WLT) (Fig. 1).

\section{DISCUSSION}

Selection of endophytic bacteria as biocontrol agent is always started with the selection of biosafety. Endophytic bacteria to be isolated should be safe for plants, animals, and the environment. Hypersensitivity test is one of test technics that is quite effective to determine whether a bacterial isolate is pathogenic potential or not. Potential pathogenic bacteria will cause a hypersensitivity reaction that is indicated by the existence of necrosis on tobacco leaves. Hypersensitivity reaction occurs as a result of hrp gene in Gram-negative pathogenic bacteria. In fact, hypersensitivity reaction is a part of a cell death program that is a form of plant defense. Plants are trying to localize the presence of pathogenic bacteria by killing cells around pathogen. This cell death occurs very fast and commonly known as the hypersensitivity reaction (Klement and Goodman, 1967). Moreover, as a biocontrol agent, endophytic bacteria also have 

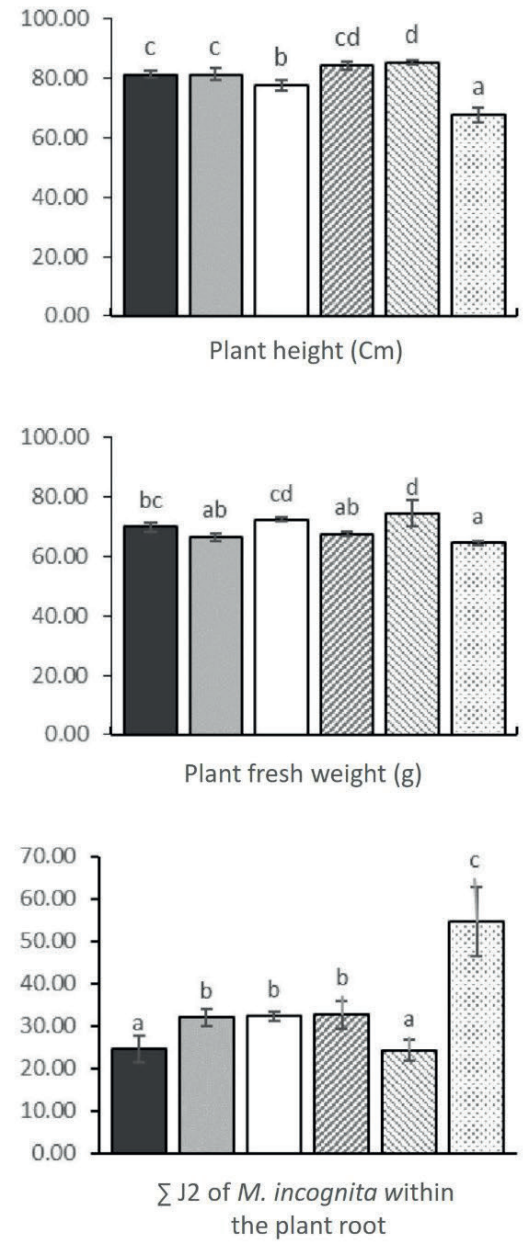
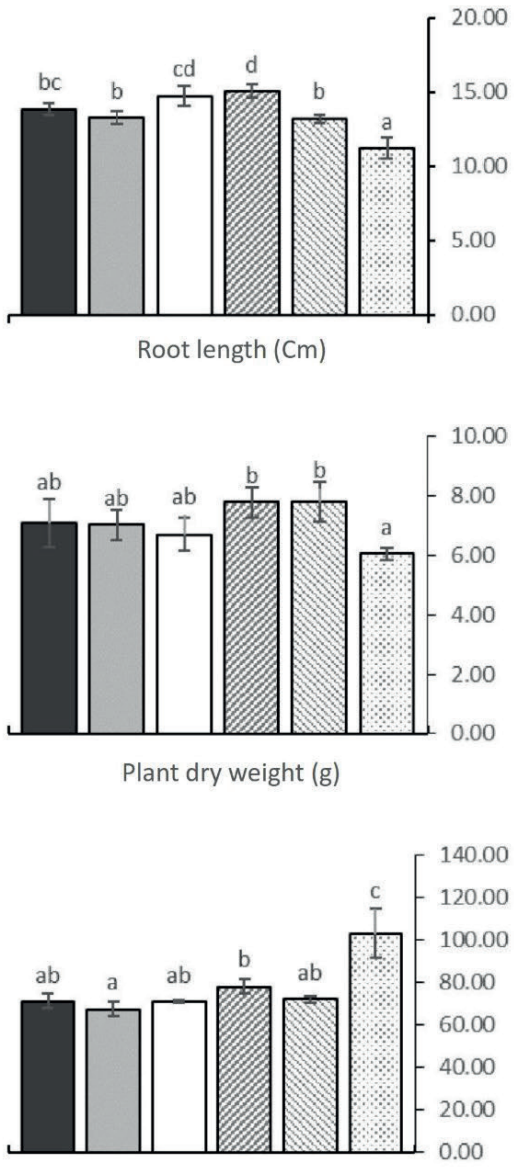

$\sum \mathrm{J} 2$ of $M$. incognita in soil

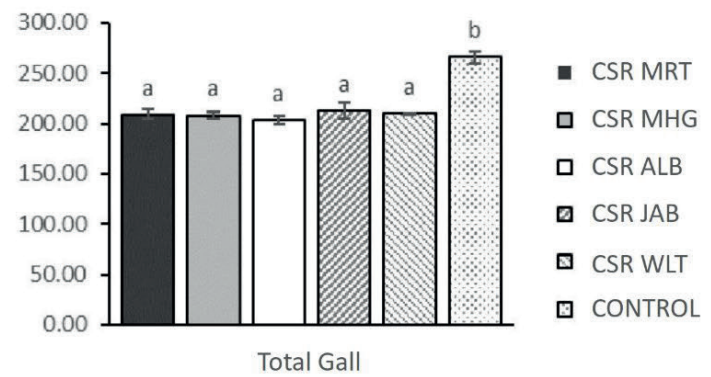

1: Effect of endophytic bacterial consortia of CSR MRT, CSR MHG, CSR ALB, CSR JAB, and CSR WLT on tomato plant growth and number of J2 of $M$. incognita and gall on each test plant

Note: values followed by different letters are significantly different over control

to be safe for human and animal. Endophytic bacteria that have the ability to produce hemolytic toxins cannot be used as a biocontrol agent. The hemolytic toxin is highly cytotoxic to blood cells such as granulocytes, monocytes, and lymphocytes (Figueroa-López et al., 2016; Gadeberg et al., 1983).

As a biocontrol agent, the endophytic bacterial consortium is reported to have better performance compared to the application of single bacteria. Each bacteria has different characters from others
(Thakkar and Saraf, 2015). Some bacteria are able to fix free nitrogen. The ability of bacteria to fix nitrogen will be beneficial in providing nitrogen element for plants. Furthermore, some other bacteria are also reported to dissolve phosphate in the soil. Several genera identified to have the ability to dissolve phosphate are Pseudomonas and Bacillus. Phosphate is highly available in the soil, yet only $1 \%$ of the total amount that can be utilized by plants. Phosphate in soil may be unavailable for plants due 
to acidic soil condition, high $\mathrm{Al}$ content, and other factors (Khan et al., 2007; Walpola and Yoon, 2012).

The result of this study showed that the filtrate culture of endophytic bacteria was effective to inhibit egg hatching of $M$. incognita and increase mortality of $\mathrm{J} 2$ of $M$. incognita in vitro. The ability of endophytic bacteria to inhibit the growth of pathogen is affected by its ability to produce secondary metabolites. Several secondary metabolites found to be effective to inhibit pathogenic nematode include protease and chitinase enzymes. Both enzymes are able to cause lyse the cell wall of $M$. incognita and the eggs of root-knot nematodes (Khan et al., 2004).

Furthermore, it is also found that endophytic bacterial consortium was able to increase tomato growth. The ability to fix nitrogen and dissolve phosphate is one reason for the ability of endophytic bacteria to boost plant growth. In the previous study, nitrogen-fixing endophytic bacteria were reported to successfully increased the growth of plants (Lodewyckx et al., 2002). In addition, phosphate-solubilizing endophytic bacteria isolated from weed Cyperus rotundus were also effective in improving tomato growth (Mardhiana et al., 2017).

The ability of endophytic bacteria to fix nitrogen and dissolve phosphate has a close relationship with its ability to promote plant growth. Nitrogen and phosphate are essential nutrients needed by plants in quite high quantities. Both are responsible for supporting vegetative and generative growth in plants. The ability of endophytic bacteria to fix nitrogen and dissolve phosphate has been reported by previous researchers such as Elbeltagy et al. (2001) and Dong et al. (1994).

The results showed that tomato plants treated with the consortium of endophytic bacteria had better growth parameter. In addition, the application of endophytic bacteria is also able to reduce the severity and population of $M$. incognita on the soil and at the tomato plant roots. This is closely related to the ability of endophytic bacteria to produce secondary metabolites. Compant et al. (2005) reported that endophytic bacteria that able to produce extracellular enzymes have a potential as a biocontrol agent. In addition, HCN produced by endophytic bacteria also plays a role in reducing the severity of infection and the population of $M$. incognita in the soil and at the tomato plant roots. $\mathrm{HCN}$ is a volatile compound that is toxic to pathogens. In a previous study, Backman and Sikora (2008) reported that endophytic bacteria that able to produce HCN have a potential as a biocontrol agent.

\section{CONCLUSION}

According to the study result, it is informed that endophytic bacterial consortium originated from forestry plants is potential as biocontrol agent as well as agent to promote plant growth. Each endophytic bacterial consortium consists of bacteria with the ability to produce enzymes (protease, chitinase, lipase) and HCN. Moreover, each endophytic bacterial consortium also consists of bacteria that are able to fix nitrogen and dissolve phosphate. The entire endophytic bacterial consortium has good performance in promote plant growth, and also suppresses root damage due to infection of M. incognita. Plants that were treated using the endophytic bacterial consortium had better growth compared to plants without the endophytic bacterial consortium treatment.

\section{REFERENCES}

ABO-ELYOUSR, K., KHAN, Z. and ABEDEL-MONEIM, M. 2010. Evaluation of plant extracts and Pseudomonas for control of root-knot nematode, Meloidogyne incognita on tomato. Nematropica, 40(2): 289-299.

ASHOUB, A. and AMARA, M. 2010. Biocontrol activity of some bacterial genera against root-knot nematode, Meloidogyne incognita. Journal of American Science, 6(10): 321-328.

BACKMAN, P. A. and SIKORA, R. A. 2008. Endophytes: an emerging tool for biological control. Biological Control, 46(1): 1-3.

BALDANI, J., BALDANI, V., SELDIN, L. and DÖBEREINER, J. 1986. Characterization of Herbaspirillum seropedicae gen. nov., sp. nov., a root-associated nitrogen-fixing bacterium. International Journal of Systematic and Evolutionary Microbiology, 36(1): 86-93.

BERTRAND, B., NUNEZ, C. and SARAH, J. L. 2000. Disease complex in coffee involving Meloidogyne arabicida and Fusarium oxysporum. Plant Pathology, 49(3): 383-388.

BHATTI, D. and JAIN, R. K. 1977. Estimation of loss in okra, tomato and brinjal yield due to Meloidogyne incognita. Indian Journal of Nematology, 7(1): 37-41.

CLAUS, D. 1992. A standardized Gram staining procedure. World Journal of Microbiology and Biotechnology, 8(4): 451-452.

COMPANT, S., DUFFY, B., NOWAK, J., CLÉMENT, C. and BARKA, E. A. 2005. Use of plant growthpromoting bacteria for biocontrol of plant diseases: principles, mechanisms of action, and future prospects. Applied Environmental Microbiology, 71(9): 4951-4959. 
DONG, Z., CANNY, M. J., MCCULLY, M. E., ROBOREDO, M. R., CABADILLA, C. F., ORTEGA, E. and RODES, R. 1994. A nitrogen-fixing endophyte of sugarcane stems (a new role for the apoplast). Plant Physiology, 105(4): 1139-1147.

ELBELTAGY, A., NISHIOKA, K., SATO, T., SUZUKI, H., YE, B., HAMADA, T., ISAWA, T., MITSUI, H. and MINAMISAWA, K. 2001. Endophytic colonization and in planta nitrogen fixation by a Herbaspirillum sp. isolated from wild rice species. Applied Environmental Microbiology, 67(11): 5285-5293.

EL-DEEB, B., FAYEZ, K. and GHERBAWY, Y. 2013. Isolation and characterization of endophytic bacteria from Plectranthus tenuiflorus medicinal plant in Saudi Arabia desert and their antimicrobial activities. Journal of Plant Interactions, 8(1): 56-64.

EPPO. 2013. PM 7/119 (1) Nematode extraction. EPPO Bulletin, 43(3): 471-495.

FIGUEROA-LÓPEZ, A. M., CORDERO-RAMÍREZ, J. D., MARTÍNEZ-ÁLVAREZ, J. C., LÓPEZ-MEYER, M., LIZÁRRAGA-SÁNCHEZ, G. J., FÉLIX-GASTÉLUM, R., CASTRO-MARTÍNEZ, C. and MALDONADOMENDOZA, I. E. 2016. Rhizospheric bacteria of maize with potential for biocontrol of Fusarium verticillioides. SpringerPlus, 5(1): 330-341.

GADEBERG, O., ORSKOV, I. and RHODES, J. M. 1983. Cytotoxic effect of an alpha-hemolytic Escherichia coli strain on human blood monocytes and granulocytes in vitro. Infection and Immunity, 41(1): 358-364.

HACKENBERG, C., MUEHLKCHEN, A., FORGE, T. and VRAIN, T. 2000. Pseudomonas chlororaphis strain Sm3, bacterial antagonist of Pratylenchus penetrans. Journal of Nematology, 32(2): 183-189.

HALLMANN, J., BERG, G. and SCHULZ, B. 2006. Isolation procedures for endophytic microorganisms. In: SCHULZ, B. J. E., BOYLE, C. J. C. and SIEBER, T. N. (Eds.). Microbial Root Endophytes. Springer.

HALLMANN, J., MEKETE, T., SIKORA, R. and KIEWNICK, S. 2009. Endophytic bacteria from Ethiopian coffee plants and their potential to antagonise Meloidogyne incognita. Nematology, 11(1): 117-127.

HARNI, R. and MUNIF, A. 2012. he Use of endophytic biological agents to control of yellow disease in black pepper [in Indonesian: Pemanfaatan agens hayati endofit untuk mengendalikan penyakit kuning pada tanaman lada]. Jurnal Tanaman Industri dan Penyegar, 3(3): 201-206.

IRMA, A., MERYANDINI, A. and RUPAEDAH, B. 2018. Biofungicide producing bacteria: an in vitro inhibitor of Ganoderma boninense. Hayati Journal of Biosciences, 25(4): 151-159.

KHAN, A., WILLIAMS, K. L. and NEVALAINEN, H. K. 2004. Effects of Paecilomyces lilacinus protease and chitinase on the eggshell structures and hatching of Meloidogyne javanica juveniles. Biological Control, 31(3): 346-352.

KHAN, M. S., ZAIDI, A. and WANI, P. A. 2007. Role of phosphate-solubilizing microorganisms in sustainable agriculture-a review. Agronomy for Sustainable Development, 27(1): 29-43.

KLEMENT, Z. and GOODMAN, R. 1967. The hypersensitive reaction to infection by bacterial plant pathogens. Annual Review of Phytopathology, 5(1): 17-44.

KUMAR, A., KUMAR, A., DEVI, S., PATIL, S., PAYAL, C. and NEGI, S. 2012. Isolation, screening and characterization of bacteria from rhizospheric soils for different plant growth promotion (PGP) activities: an in vitro study. Recent Research in Science and Technology, 4(1): 1-5.

LODEWYCKX, C., VANGRONSVELD, J., PORTEOUS, F., MOORE, E. R., TAGHAVI, S., MEZGEAY, M. and DER LELIE, D. V. 2002. Endophytic bacteria and their potential applications. Critical Reviews in Plant Sciences, 21(6): 583-606.

MARDHIANA, M., PRADANA, A. P., ADIWENA, M., SANTOSO, D., WIJAYA, R. and MURTILAKSONO, A. 2017. Use of endophytic bacteria from roots of Cyperus rotundus for biocontrol of Meloidogyne incognita. Biodiversitas, 18(4): 1308-1315.

MEHTA, S. and NAUTIYAL, C. S. 2001. An efficient method for qualitative screening of phosphatesolubilizing bacteria. Current Microbiology, 43(1): 51-56.

MOENS, M., PERRY, R. N. and STARR, J. L. 2009. Meloidogyne species-a diverse group of novel and important plant parasites. In: PERRY, R. N., MOENS, M. and STARR, J. L. (Eds.). Root-Knot Nematodes. CABI.

NURDEBYANDARU, N., MUBARIK, N. R. and PRAWASTI, T. S. 2010. Chitinolytic bacteria isolated from chili rhizosphere: chitinase characterization and application as biocontrol for Aphis gossypii. Microbiology Indonesia, 4(3): 103-107.

PADGHAM, J. and SIKORA, R. 2007. Biological control potential and modes of action of Bacillus megaterium against Meloidogyne graminicola on rice. Crop Protection, 26(7): 971-977.

PRADANA, A. P., MUNIF, A. and SUPRAMANA, S. 2016. Endophytic bacteria from root of several plants as biocontrol agents of the root-knot nematode Meloidogyne incognita on tomato [in Indonesian: Bakteri endofit asal berbagai akar tanaman sebagai agens pengendali nematoda puru akar Meloidogyne incognita pada tomat]. Jurnal Fitopatologi Indonesia, 12(3): 75-82.

REINHOLD-HUREK, B. and HUREK, T. 2011. Living inside plants: bacterial endophytes. Current Opinion in Plant Biology, 14(4): 435-443. 
RICH, J., BRITO, J., KAUR, R. and FERRELL, J. 2009. Weed species as hosts of Meloidogyne: a review. Nematropica, 39(2): 157-185.

ROSENBLUETH, M. and MARTÍNEZ-ROMERO, E. 2006. Bacterial endophytes and their interactions with hosts. Molecular Plant-Microbe Interactions, 19(8): 827-837.

RYAN, R. P., GERMAINE, K., FRANKS, A., RYAN, D. J. and DOWLING, D. N. 2008. Bacterial endophytes: recent developments and applications. FEMS Microbiology Letters, 278(1): 1-9.

SHORESH, M., HARMAN, G. E. and MASTOURI, F. 2010. Induced systemic resistance and plant responses to fungal biocontrol agents. Annual Review of Phytopathology, 48: 21-43.

SOKOL, P. A., OHMAN, D. E. and IGLEWSKI, B. H. 1979. A more sensitive plate assay for detection of protease production by Pseudomonas aeruginosa. Journal of Clinical Microbiology, 9(4): 538-540.

THAKKAR, A. and SARAF, M. 2015. Development of microbial consortia as a biocontrol agent for effective management of fungal diseases in Glycine max L. Archives of Phytopathology and Plant Protection, 48(6): 459-474.

WALPOLA, B. C. and YOON, M.-H. 2012. Prospectus of phosphate solubilizing microorganisms and phosphorus availability in agricultural soils: A review. African Journal of Microbiology Research, 6(37): 6600-6605.

WIRATNO, W., SYAKIR, M., SUCIPTO, I. and PRADANA, A. P. 2019. Isolation and characterization of endophytic bacteria from roots of Piper nigrum and their activities against Fusarium oxysporum and Meloidogyne incognita. Biodiversitas, 20(3): 682-687.

ZAKIR, H. and BORA, B. 2009. Interrelationship of Meloidogyne incognita and Ralstonia solanacearum complex in brinjal. Indian Journal of Nematology, 39(1): 41-45. 